Iranica Journal of Energy \& Environment 2 (3): 229-234, 2011

ISSN 2079-2115

IJEE an Official Peer Reviewed Journal of Babol Noshirvani University of Technology

doi: 10.5829/idosi.ijee.2011.02.03.1519

\title{
Performance of Anaerobic Baffled Reactor for Biodegradation of Phenol
}

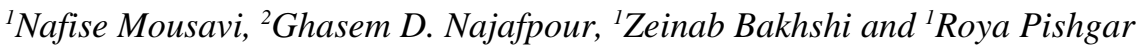 \\ ${ }^{1}$ School of Civil Engineering, Babol Noshirvani University of Technology, Babol, Iran \\ ${ }^{2}$ School of Chemical Engineering, Babol Noshirvani University of Technology, Babol, Iran
}

(Received: June 5, 2011; Accepted: July 29, 2011)

\begin{abstract}
Effect of increase in phenol concentration on performance of anaerobic baffled reactor in terms of chemical oxygen demand (COD), phenol and COD removal efficiency and biogas productions was investigated. Furthermore, stability of the reactor with respect to the chemical shock load was monitored. The anaerobic baffled reactor was continuously operated with synthetic wastewater. The obtained results showed that adopted sludge improved the reactor performance. The start-up strategy used for this process has achieved to the targeted goals while the active microbial population was retained. For the initial stage of operation, there was no phenol present in the system. Then, the phenol concentrations were gradually and stepwise increased from 10 to $800 \mathrm{mg} / \mathrm{L}$ at hydraulic retention time (HRT) of 6 days. At loading rate of $0.5 \mathrm{~g} \mathrm{COD} / \mathrm{L} /$ day, maximum phenol removal efficiency of $96 \%$ was achieved. COD removal efficiency was quite high in the first compartment of baffled reactor, while the efficiency and the COD removal gradually dropped in the second and third compartments. In the bioreactor, low value of $\mathrm{pH}$ in the first compartment was due to acid generated by the acidogenic bacteria.
\end{abstract}

Key words: Phenol \%Anaerobic baffled reactor \%Acidogenic bacteria \%Industrial wastewater \%Biodegradation

\section{INTRODUCTION}

Phenols of anthropogenic origin exist in the environment due to various activities such as petroleum refinery wastes, coal conversion process, coke oven effluents, coal processing, metallurgic $[1,2]$ and pulp and paper mill effluents [3]. Due to the high toxicity and widespread penetration of the toxic and carcinogenic compounds to ecosystem, many research scientists have conducted investigations on preservation and control of environmental pollutants for the removal of toxic and hazardous compounds [2]. According to standards defined by the European Union (EU) Directive 2455/2001/EC, maximum allowable limit of phenol in drinking water is $0.5 \mu \mathrm{g} / \mathrm{l}$. Phenols are reported to be highly toxic to fish at concentration of 5-25 mg/l [4].

Among various treatment methods for the removal of toxic compounds, biodegradation is the leading method which has high acceptance by public [4]. In biological treatment methods, phenols can be harmlessly degraded and this process is cost effective compared to physicochemical methods [5]. However, it must be noted that problems are arising from the antimicrobial feature and toxicity of these by-products such as cresols, resorcinol and hydroquinone. The disadvantages should be overcome by some skillful programming such as using co-substrate defined as glucose [6] for the bioaugmentation [7]. In addition, acclimatization method to save microbial cells from toxicity and inhibitory effects is well recommended [8].

Biodegradation of phenolic compounds can be accomplished by several biological processes such as up flow anaerobic sludge blanket reactor (UASB), anaerobic continuous stirred tank reactor (ACSTR) and anaerobic baffled reactor (ABR) [9]. These processes offer number of advantages over aerobic systems such as: generation of methane as fuel, no oxygenation demand, being compact and producing less biological sludge [10]. The use of anaerobic baffled reactor has been recommended in the literatures as a high rate system for industrial wastewater treatment [11].

Corresponding Author: Dr. Ghasem D. Najafpour, School of Chemical Engineering, Babol Noshirvani University of Technology, Babol, Iran. E-mails: najafpour@ni.ac.ir \& najafpour8@yahoo.com. 
The ABR is extensively applied for treating heavy oil produced effluents [12], cassava wastewater [13], low strength complex discharge [14], wheat flour starch industrial disposal [15], acidic and zinc-containing effluents [16], palm oil mill effluent [17] and municipal wastewater treatment [18].

There was limited availability of literature regarding the use of ABR for phenol biodegradation [11, 19]. There is a relative lack of research on reactor start up, adoption period and microbial decomposition and effective parameters on reactor performance. Present study investigates the feasibility of an anaerobic baffled reactor for the biodegradation of phenol with supplementary substrate. Biomass washout, COD, phenol removal efficiency and acclimatization of the biomass along with phenol concentration changes was further investigated.

\section{MATERIALS AND METHOD}

Reactor Configuration: The reactor was fabricated by Plexiglas with a total volume of 36 and working volume of $28 \mathrm{~L}$. The schematic representation of the experimental set up is shown in Fig. 1. The reactor consists of three compartments with dimensions of $15 \mathrm{~cm}$ width, $60 \mathrm{~cm}$ length and $40 \mathrm{~cm}$ depth. The up flow chamber width was designed with a ratio of 3.5:1 to down comer one. The lower section of the down comer baffles had a $4 \mathrm{~cm}$ separated space from the bottom of the reactor. The lower section was bent with an angle of $45 \mathrm{E}$ in order to lead the flow equally through the up flow chambers and also to obtain a better contact between feed and the retained biosolids. The upper portions of the risers were designed in a descending manner in order to overcome the problems rising from head depletion as the flow gently passes through the baffles. Sampling ports for collecting sludge samples and wastewater were located at $3 \mathrm{~cm}$ above the bottom of up flow chambers. A peristaltic pump was used to adjust the influent flow rate.

Acclimated Sludge Inoculation: The seed sludge was anaerobically acclimated with phenolic wastewater obtained from the pulp and paper wastewater treatment plant (Sari, Iran). The thickened sludge was introduced into the three compartments of reactor. The working volume in compartment 1,2 and 3 were 9.9, 9.6 and $8.8 \mathrm{~L}$, respectively. The volumes of acclimated sludge introduced into compartment 1, 2 and 3 were 3,2 and $1 \mathrm{~L}$, respectively.

Feed Composition: The ABR was initially fed with phenol as primary substrate and glucose as co-substrate. The phenol solution with a concentration of $3000 \mathrm{mg} / \mathrm{L}$ was prepared. In the course of investigation, favourable phenol concentrations were obtained by dilution of phenol stock solution with distilled water. Microelement solution was prepared at 600 times concentration. To avoid increasing VFA (volatile fatty acid), 1000-2000 mg/L $\mathrm{NaHCO}_{3}$ was added to the reactor. Table 1 summarizes the synthetic feed composition of ABR [20].

Analytical Methods: COD of samples were determined using closed reflux colorimetric method and Phenol content in compartments and effluent was measured by 4aminoantipyrine method; all in accordance with APHA and AWWA standard methods [21]. The biogas production was determined with volume displacement of biogas saturated water. The $\mathrm{pH}$ was measured with a digital $\mathrm{pH}$ meter electrode (HANNA, Germany).

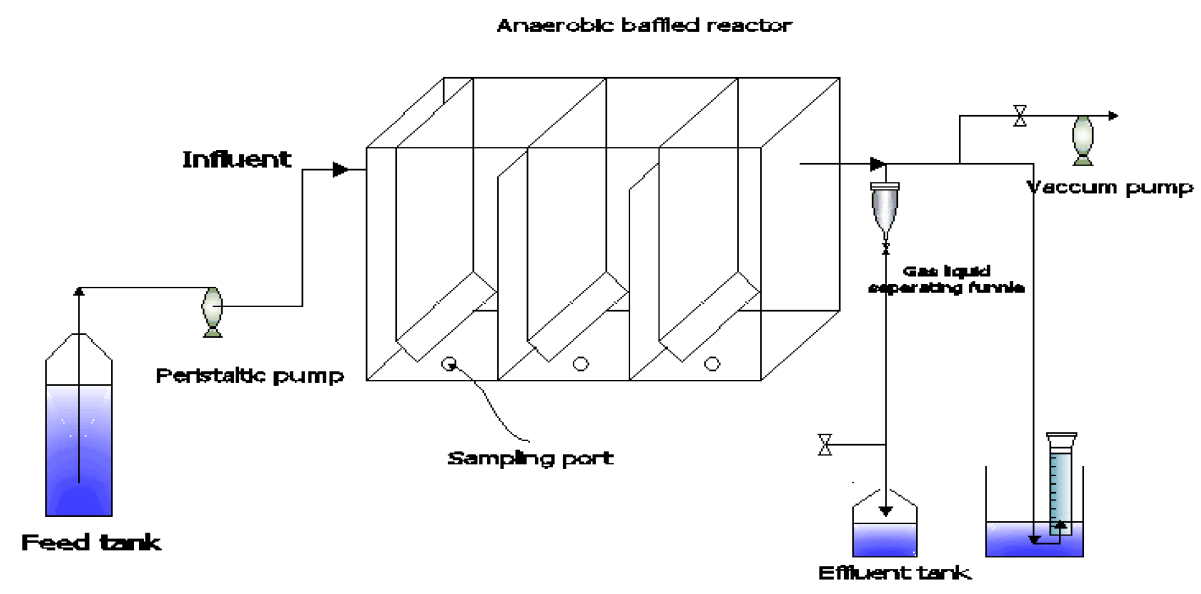

Fig. 1: Schematic representation of the anaerobic baffled reactor (ABR) 
Table 1: Feed compositions

\begin{tabular}{ll}
\hline Feed composition & Concentration $(\mathrm{mg} / \mathrm{L})$ \\
\hline COD components & $100-1000$ \\
Phenol concentration & 1000 \\
Glucose concentration & $245-2300$ (phenol) / 950 (glucose) \\
\hline Macro elements & \\
$\mathrm{KCl}$ & 200 \\
$\mathrm{NH}_{4} \mathrm{Cl}$ & 50 \\
$\mathrm{NaHCO}_{3}$ & $1000-2000$ \\
$\mathrm{CaCl}_{2} \cdot 2 \mathrm{H}_{2} \mathrm{O}$ & 150 \\
$\mathrm{MgCl}_{2}$ & 100 \\
\hline $\mathrm{Microelements}^{2}$ & \\
$\mathrm{FeCl}_{2} \cdot 4 \mathrm{H}_{2} \mathrm{O}$ & 10 \\
$\mathrm{CoCl}_{2} \cdot 2 \mathrm{H}_{2} \mathrm{O}$ & 0.02 \\
$\mathrm{NiCl}_{2} \cdot 6 \mathrm{H}_{2} \mathrm{O}$ & 0.02 \\
$\mathrm{ZnCl}_{2}$ & 0.02 \\
$\mathrm{CuCl}_{2} \cdot 2 \mathrm{H}_{2} \mathrm{O}$ & 0.02 \\
$\mathrm{MnCl}_{2} \cdot 4 \mathrm{H}_{2} \mathrm{O}$ & 0.02 \\
$\mathrm{NaMoO}_{4} \cdot 2 \mathrm{H}_{2} \mathrm{O}$ & 0.05 \\
$\mathrm{H}_{3} \mathrm{BO}_{3}$ & 0.02 \\
\hline
\end{tabular}

Anaerobic Baffled Reactor Operation: In start-up period for duration of 17 days, the initial activity of the sludge was enhanced; initially the reactor was fed with glucose as the sole carbon source. After that, the reactor was fed with variable phenol concentration with initial phenol concentration of $100 \mathrm{mg} / \mathrm{L}$; then the concentration was stepwise increased to $800 \mathrm{mg} / \mathrm{L}$.

All the detailed information was gathered under steady state conditions which were attained when COD removal reached to $80-90 \%$ of its efficiency. All collected data were replicated for precise and reliable results.

\section{RESULTS AND DISCUSSION}

Start-up of Anaerobic Baffle Reactor: It was reported that presence of an easy biodegradable substrate such as glucose has many advantages over systems which are treating inhibitory substances as single substrate. This can lead to an accelerated start up process and adaptation period also can improve the system stability [22]. Additional fact was the use of a co-substrate which may cause the methanogens remain in active phase while biomass is acclimatized to the xenobiotic substrate $[1,23]$.

Taking into consideration the importance of adaptation period, reactor was first inoculated with seed sludge in order to acquaint inocula with anaerobic condition of the ABR. The reactor was initially operated for 17 days with $1000 \mathrm{mg} / \mathrm{L}$ glucose as the single carbon

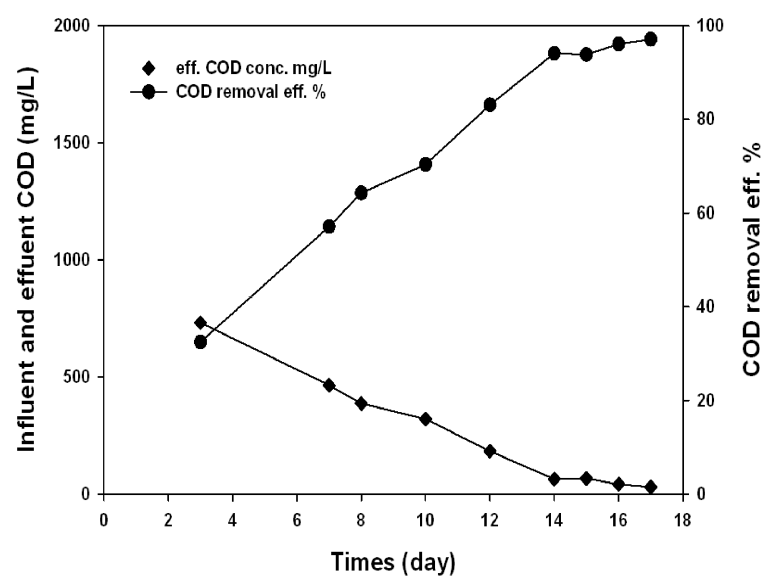

Fig. 2: COD variation for the reactor start up initially with glucose $(1000 \mathrm{mg} / \mathrm{L})$

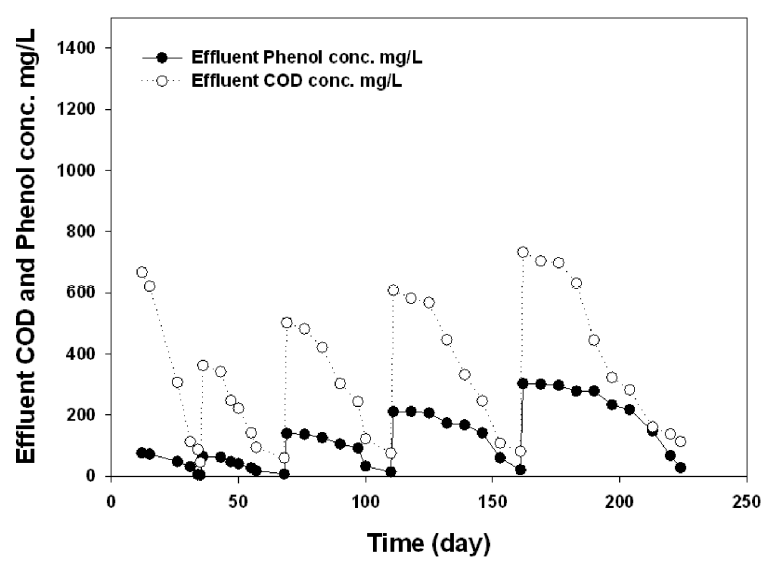

Fig. 3: COD and phenol profiles in the ABR

source. Fig. 2 represents the COD removal efficiency in the rector for the start up period. All the data were collected after 3 days of the reactor operation. The COD removal efficiency on the third day of operation was $32 \%$. The removal efficiency was significantly improved to 94 and $97 \%$ after 14 and 17 days, respectively. The reactor proved to be very stable after a few days of operation and after one week a steady state condition was easily achieved. At the end of the bioactive enrichment phase, the COD removal efficiency was maintained above $95 \%$.

Performance of Anaerobic Baffled Reactor: After the initial stage of operation with glucose as the sole source of energy, the reactor was gradually fed with phenol as carbon source. The initial phenol concentration was 100 $\mathrm{mg} / \mathrm{L}$ and once satisfactory phenol removal efficiency of $80-90 \%$ was achieved the phenol concentration stepwise increased to 200, 400, 600 and $800 \mathrm{mg} / \mathrm{L}$ (equivalent to 0.5 g COD/L/day) which resulted in organic loading rate (OLR) of $0.22,0.26,0.34$ and 0.41 , respectively. 


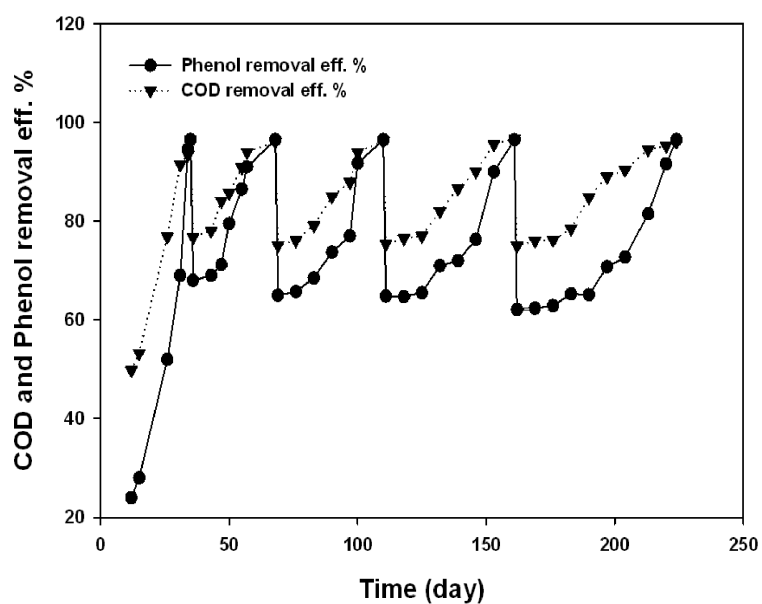

Fig. 4: Effect of phenol concentration on COD and phenol removal efficiencies in the ABR

Figs. 3 and 4 show the reactor performance in response to elevated phenol concentration. Samples were withdrawn 3 days after adding phenol to synthetic wastewater with phenol and glucose concentrations of 100 and $1000 \mathrm{mg} / \mathrm{L}$, respectively. The equivalent amount of organic level was $1329 \mathrm{mg} / \mathrm{L}$ of COD. At $20^{\text {th }}$ day of operation, the removal efficiency of COD and phenol dropped to 49 and 24\%, respectively. As the operation was prolonged to 42 days, the reactor recovered and gained its high removal efficiency of $89 \%$ and even reached to $96 \%$ at $50^{\text {th }}$ day of the reactor operation. Once the stability of the reactor was confirmed after adaptation to phenolic compound, the concentration of phenol was gradually increased to 200, 400, 600 and $800 \mathrm{mg} / \mathrm{L}$. The obtained data demonstrated that the degradation time noticeably increased when the phenol concentration was gradually increased. Reactor easily degraded $100 \mathrm{mg} / \mathrm{L}$ phenol with high efficiently within 24 days; while the influent phenol concentration increased to $800 \mathrm{mg} / \mathrm{L}$ degradation was prolonged to about 60 days and the removal efficiency enhanced to range of 80 to $90 \%$.

Fig. 5 depicts biogas production rate from the $20^{\text {th }}$ day of operation, while $100 \mathrm{mg} / \mathrm{l}$ of phenol was introduced to influent as additional carbon source. Initially, the rate of total biogas production was very low $(0.5 \mathrm{~L} / \mathrm{d})$. Biogas production profile indicated that total gas production rate was gradually increased along with phenol increments in the feed solution. At the end of the first stage of adding $100 \mathrm{mg} / \mathrm{l}$ phenol as the single substrate; the reactor had reached to $96 \%$ of removal efficiency, with biogas production rate of $2.3 \mathrm{~L} / \mathrm{d}$.

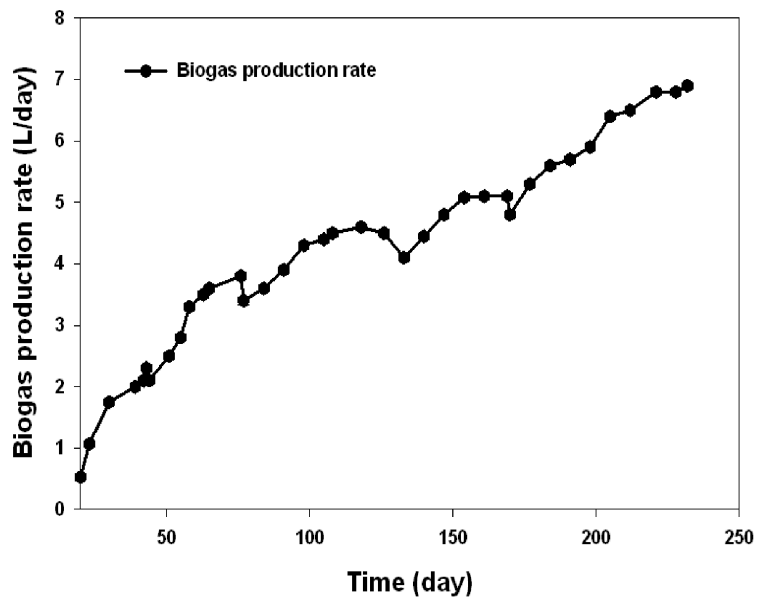

Fig. 5: Total biogas production rate (L/day)

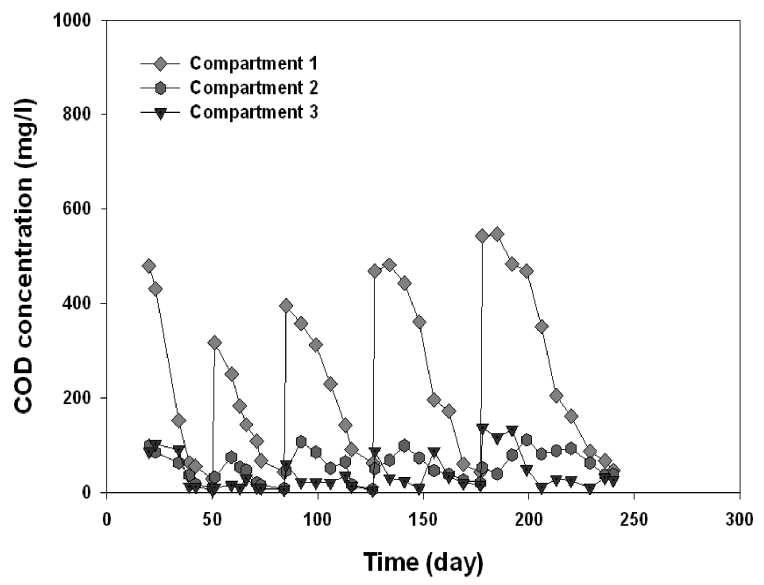

Fig. 6: The COD concentration in 3 compartments of the $\mathrm{ABR}(\mathrm{mg} / \mathrm{L})$ and COD removal efficiency (\%)

The COD concentration profile is shown in Fig. 6 . Maximum COD removal efficiencies in the ABR compartments 1, 2 and 3 were 42-89, 6-35 and 4-24\%, respectively. This indicated that the acidogenesis phase and VFA production occurred in compartment 1 while in the next stage, the methanogens populations were probably active for the accomplishment of anaerobic process.

Effect of Shock Loads: After steady state conditions were achieved the reactor was continuously operated for the duration of 224 days. The reactor OLR was raised to 0.85 g COD/L/day, with lowering HRT to the lowest value of $4 \mathrm{~h}$ and increasing phenol concentration to $1000 \mathrm{mg} / \mathrm{l}$ as demonstrated in Fig. 7. The obtained results showed a collapse in phenol removal efficiency to $42 \%$. On $262^{\text {nd }}$ day, the shock load applied to the system was gradually recovered to $73 \%$. When phenol concentration and HRT 


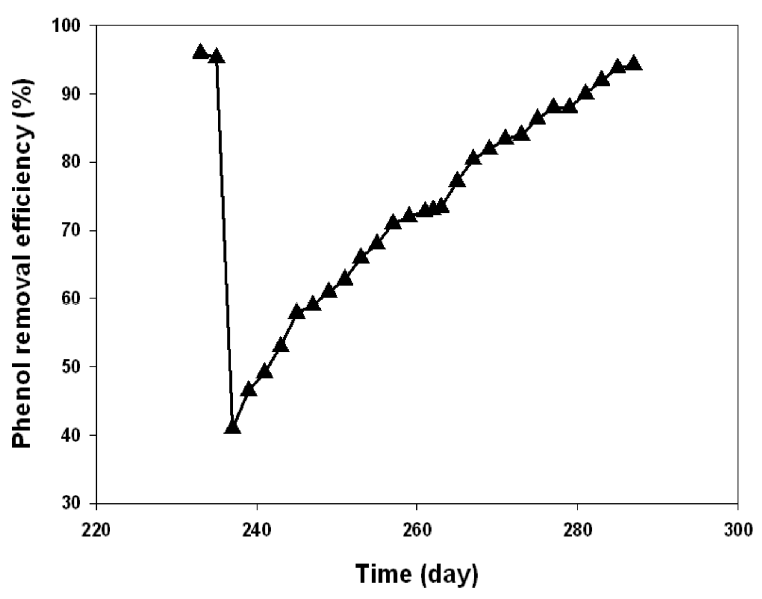

Fig. 7: Response of the ABR to chemical shock loads

was shifted back to its initial value of $800 \mathrm{mg} / \mathrm{l}$ and 6 days, system was successfully capable of recovering from the shock load. Therefore, the phenol removal efficiency reached to $93 \%$ on the $296^{\text {th }}$ day. In fact, this result confirmed the inherent characteristic of the process stability, against organic shock loads owing to the compartmentalized structure of the reactor.

Treatability in this work (HRT of 6days) was higher than ABR which was treating $p$-nitrophenol (PNP) at hydraulic retention time of 10.38 days [11].

\section{CONCLUSION}

In this study, the biodegradation of phenol along with glucose as supplementary carbon source in an anaerobic baffled reactor was successfully accomplished. Use of glucose as a co-substrate and acclimated seed sludge had appreciably improved the biodegradation process by shortening the start up period and lowering the duration time. Maximum phenol concentration of 800 $\mathrm{mg} / \mathrm{L}$ (equivalent to $0.5 \mathrm{~g}$ COD/L/day) was applied and $96 \%$ removal efficiency was achieved while the remaining phenol concentration in the effluent was $28 \mathrm{mg} / \mathrm{L}$. It was concluded that prolongation HRT from 6 to 8 days, the reactor effluent can easily achieved the defined international standards. Lowering the $\mathrm{pH}$ values in the compartment 1 rather than compartment 2 and 3 indicated the high performance of the reactor in behaving as a twophase system for the high achievement of anaerobic sequential stages such as hydrolysis followed by acidogenesis and methanogenis. ABR was completely able to recover from the shock load at 34 days after switching OLR to its initial value. This result showed the stability of the process against hydraulic and organic shock loads.

\section{ACKNOWLEDGEMENTS}

Authors are thankful and acknowledge the facilities provided in Biotechnology Research Lab at Babol Noshirvani University of Technology to conduct present research.

\section{REFERENCES}

1. Veeresh, Kumar and Mehrotra, 2005. Treatment of phenol and cresols in upflow anaerobic sludge blanket (UASB) process: a review. Water Research, 39(1): 154-170.

2. Micha Owicz and Duda, 2007. Phenols-sources and toxicity. Pol. J. Environ. Stud., 16: 347-362.

3. Pandey, 2004. Concise encyclopedia of bioresource technology. CRC.

4. Ramakrishnan and Gupta, 2006. Anaerobic biogranulation in a hybrid reactor treating phenolic waste. Journal of hazardous materials, 137(3): 1488-1495.

5. Lin, J., 2008. Bacterial removal of toxic phenols from an industrial effluent. African J. Biotechnol., 7(13): 2232-2238.

6. Kwon and Yeom, 2009. Optimal microbial adaptation routes for the rapid degradation of high concentration of phenol. Bioprocess and Biosystems Engineering, 32(4): 435-442.

7. Tay, Moy, Maszenan and Tay, 2005. Comparing activated sludge and aerobic granules as microbial inocula for phenol biodegradation. Appl. Microbiol. Biotechnol., 67(5): 708-713.

8. Jiang, Tay, Maszenan and Tay, 2004. Bacterial Diversity and Function of Aerobic Granules Engineered in a Sequencing Batch Reactor for Phenol Degradation. Appl. Environ. Microbiol., 70(11): 6767-6775.

9. Liu, Sheng and Yu, 2009. Physicochemical characteristics of microbial granules. Biotechnology Advances, 27(6): 1061-1070.

10. Batstone, 2005. Hydraulics of laboratory and full-scale upflow anaerobic sludge blanket (UASB) reactors. Biotechnology and Bioengineering, 91(3): 387-391, Zinatizadeh, Younesi, Bonakdari, Pirsaheb, Pazouki, Najafpour and Hasnain Isa, 2009. Effects of process factors on biological activity of granular sludge grown in an UASFF bioreactor. Renewable Energy, 34(5): 1245-1251, Liu and Tay, 2004. State of the art of biogranulation technology for wastewater treatment. Biotechnology Advances, 22(7): 533-563. 
11. Kusçu and Sponza, 2005. Performance of anaerobic baffled reactor (ABR) treating synthetic wastewater containing p-nitrophenol. Enzyme and Microbial Technology, 36(7): 888-895.

12. Ji, Sun, Ni and Tong, 2009. Anaerobic baffled reactor (ABR) for treating heavy oil produced water with high concentrations of salt and poor nutrient. Bioresource Technology, 100(3): 1108-1114.

13. Ferraz, Bruni and Del Bianchi, 2009. Performance of an Anaerobic Baffled Reactor (ABR) in treatment of cassava wastewater. Brazilian J. Microbiol., 40: 48-53.

14. Gopala Krishna, Kumar and Kumar, 2008. Treatment of low strength complex wastewater using an anaerobic baffled reactor (ABR). Bioresource Technology, 99(17): 8193-8200.

15. Movahedyan, Assadi and Parvaresh, 2007. Performance evaluation of an anaerobic baffled reactor treating wheat flour starch industry wastewater. Iranian J. Environ. Health Sci. Engineering, 4(2).

16. Bayrakdar, Sahinkaya, Gungor, Uyanik and Atasoy, 2009. Performance of sulfidogenic anaerobic baffled reactor $(\mathrm{ABR})$ treating acidic and zinc-containing wastewater. Bioresource Technol., 100(19): 4354-4360.
17. Zinatizadeh, Mohamed, Abdullah, Mashitah, Hasnain Isa and Najafpour, 2006. Process modeling and analysis of palm oil mill effluent treatment in an up-flow anaerobic sludge fixed film bioreactor using response surface methodology (RSM). Water Research, 40(17): 3193-3208.

18. Bodkhe, 2009. A modified anaerobic baffled reactor for $m$ unicipal wastewater treatment. J. Environ. Management, 90(8): 2488-2493.

19. Barber and Stuckey, 1999. The use of the anaerobic baffled reactor (ABR) for wastewater treatment: a review. Water Research, 33(7): 1559-1578.

20. Rittmann and Mccarty, 2001. Environmental biotechnology: principles and applications. McGraw-Hill New York.

21. Way and House, 2005. Standard methods for the examination of water and wastewater.

22. Subramanyam and Mishra, 2007. Biodegradation of catechol (2-hydroxy phenol) bearing wastewater in an UASB reactor. Chemosphere, 69(5): 816-824, Tay, He and Yan, 2001. Improved anaerobic degradation of phenol with supplemental glucose. J. Environ. Engineering, 127(1): 38-45.

23. Carbajo, Boltes and Leton, 2010. Treatment of phenol in an anaerobic fluidized bed reactor (AFBR): continuous and batch regime. Biodegradation, 21(4): 603-613. 